\title{
Hydrodynamic control of microphytoplankton bloom in a coastal sea
}

\author{
K Narasimha Murty, Nittala S Sarma*@; Sudarsana Rao Pandi, \\ Gundala Chiranjeevulu, Rayaprolu Kiran and R Muralikrishna \\ Marine Chemistry Laboratory, Andhra University, Visakhapatnam 530 003, India. \\ *Corresponding author. e-mail: nssarma@rediffmail.com
}

MS received 24 October 2016; revised 12 February 2017; accepted 4 April 2017; published online 31 August 2017

The influence of hydrodynamics on phytoplankton bloom occurrence/formation has not been adequately reported. Here, we document diurnal observations in the tropical Bay of Bengal's mid-western shelf region which reveal microphytoplankton cell density maxima in association with neap tide many times more than what could be accounted for by solar insolation and nutrient levels. When in summer, phytoplankton cells were abundant and the cell density of Guinardia delicatula reached critical value by tide caused zonation, aggregation happened to an intense bloom. Mucilaginous exudates from the alga due to heat and silicate stress likely promoted and stable water column and weak winds left undisturbed, the transient bloom. The phytoplankton aggregates have implication as food resource in the benthic region implying higher fishery potential, in carbon dioxide sequestration (carbon burial) and in efforts towards improving remote sensing algorithms for chlorophyll in the coastal region.

Keywords. Tidal influence; Guinardia delicatula; Trichodesmium erythraeum; Guinardia striata; remote sensing; bio-volume; chlorophyll; Bay of Bengal.

\section{Introduction}

Phytoplankton blooms attract worldwide attention because they are often harmful and affect the fishery resource of the sea, either positively or negatively. Close monitoring of phytoplankton blooms is expected to provide means to check and protect the oceanic/coastal ecosystem as well as to possibly link their occurrence to climate change (NOAA 2014). The influence of hydroptical, hydrochemical, hydrobiological and hydrogeological factors on phytoplankton abundance is known (Reynolds 2006). However, the interactive role of biological and physical factors in bloom formation is not clearly known (Prairie et al. 2012).

The Bay of Bengal in the tropical belt is a mesotrophic, less studied area, with high variability in phytoplankton distribution (Madhu et al. 2006; Prasanna Kumar et al. 2006). The Bay receives enormous fresh water flux from large and medium rivers of south Asia and through rainfall and this rainfall is affected by the Indian monsoon system consisting of seasonally reversing southwesterly (summer, May-September) and northeasterly (winter, October-January) winds (Gadgil 2003). In both the summer and winter monsoons,

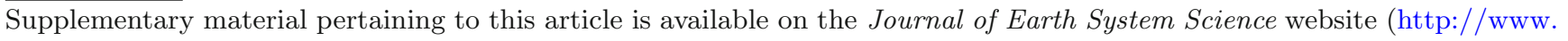
ias.ac.in/Journals/Journal_of_Earth_System_Science). 
surface nutrient enrichment can happen, but by contrasting mechanisms. The summer winds cause upwelling away from river mouths. Close to river mouths surface freshening prevents upwelling due to the presence of a stagnant layer of less saline water leading to nutrient exhaustion at surface (McCreary et al. 2009), because of which phytoplankton production is restricted (Naik et al. 2011; D'Silva et al. 2012; Latha et al. 2014). The winter winds cool the surface and promote convection of surface water to depths in regions where there is no barrier layer at the surface, which also leads to surface nutrient enrichment (Vinayachandran and Mathew 2003).

There are reports of phytoplankton blooms in the western coastal Bay of Bengal, although not as much as in the case of the eastern Arabian Sea. The reported blooms include those of diatoms (e.g., Asterionella japonica), blue green algae e.g., Trichodesmium and dinoflagellates e.g., Noctiluca (D'Silva et al. 2012 and references therein). Nutrient availability (and light) alone does not give place to blooms in the western Bay of Bengal. Turbidity-river sourced in the coastal and also by tidal action in the estuarine regions, and cloud cover can severely restrict phytoplankton production by restricting the light field (Prasanna Kumar et al. 2002). The meso-scale eddies which are common in the western Bay of Bengal may or may not favour phytoplankton production depending on whether they cause upwelling (cold-core eddy) or sinking (warm-core eddy) (Prasanna Kumar et al. 2006). A less explored but important mechanism influencing phytoplankton abundance in the coastal region is the tidal oscillations (Blauw et al. 2012).

From a practical point of view, phytoplankton blooms have chlorophyll $a>3 \mu \mathrm{g} \mathrm{L}^{-1}$, or when the (micro) phytoplankton abundance $>1000$ cells $\mathrm{ml}^{-1}$ even when chlorophyll does not exceed the threshold (Smayda 1997). Remote sensing which is routinely used to detect and monitor phytoplankton blooms is likely to miss bloom, if the bloom is transient due to hydrodynamic conditions and does not synchronize with the satellite pass. The complexities in chlorophyll retrieval based on satellite sensor data, e.g., the SeaWiFS in the Bay of Bengal (Tilstone et al. 2011) and on the regional to global scales (Siegel et al. 2013) indicate that high-resolution monitoring programs are essential in order to capture the natural variability of phytoplankton in coastal waters (Blauw et al. 2012).
The objective of this paper is to make new high frequency observations in the mid-western shelf waters of the Bay of Bengal that would potentially reveal short-lived blooms.

\section{Materials and methods}

\subsection{Study area}

The western Bay of Bengal which borders the Indian east coast, Bangladesh and Sri Lanka receives large input of freshwater through rivers at regular intervals along the coast, e.g., the GangaBrahmaputra (G-B) river system, Mahanadi, Godavari, Krishna and Cauvery and several small rivers in between. In a coastal transect off Visakhapatnam on the east coast of India whose waters are not significantly affected by these point sources, three fixed stations where the water column is 20, 30 and $50 \mathrm{~m}$ deep were sampled during eight months (June 2013-February 2014). The stations are 2, 6 and $15 \mathrm{~km}$ away from the coast respectively (figure 1).

\subsection{Collection of samples and analyses}

The water samples were collected on board $C R V$ 'Sagar Paschimi' of Ministry of Earth Sciences, India on a majority of cruises (6 of 8), and the hired ' $M F V$ Srinivasa' at other times, with the help of a Niskin bottle $(5 \mathrm{~L})$ from surface $(-1 \mathrm{~m})$, and 10, 20, 30 and $50 \mathrm{~m}$ depths. The sampling was at $2 \mathrm{hr}$ intervals during the day time (08:00, 10:00, 12:00, 14:00, 16:00 hrs) at the $50 \mathrm{~m}$ bathymetric station $\left(17^{\circ} 44.46^{\prime} \mathrm{N}, 83^{\circ} 29.6^{\prime} \mathrm{E}\right)$. At the other stations ( 20 and $30 \mathrm{~m}$ bathymetries), the sampling was done once while transiting to/from the time series station. A Seabird Electronics CTD measured the salinity and temperature. Standard methods were used carefully avoiding introduction of artifacts and using duplicates wherever necessary for the chemical analyses (dissolved oxygen and nutrients), measurement of $\mathrm{pH}$ and turbidity, and chlorophyll $a$ estimation and (lugol's iodine fixed) phytoplankton enumeration adopting standard microscopic methods (UNESCO 1978; Chari et al. 2013a). Pearson correlation analysis was done for the phytoplankton abundance and bio-volume data, chlorophyll and nutrient concentrations in excel worksheets. 


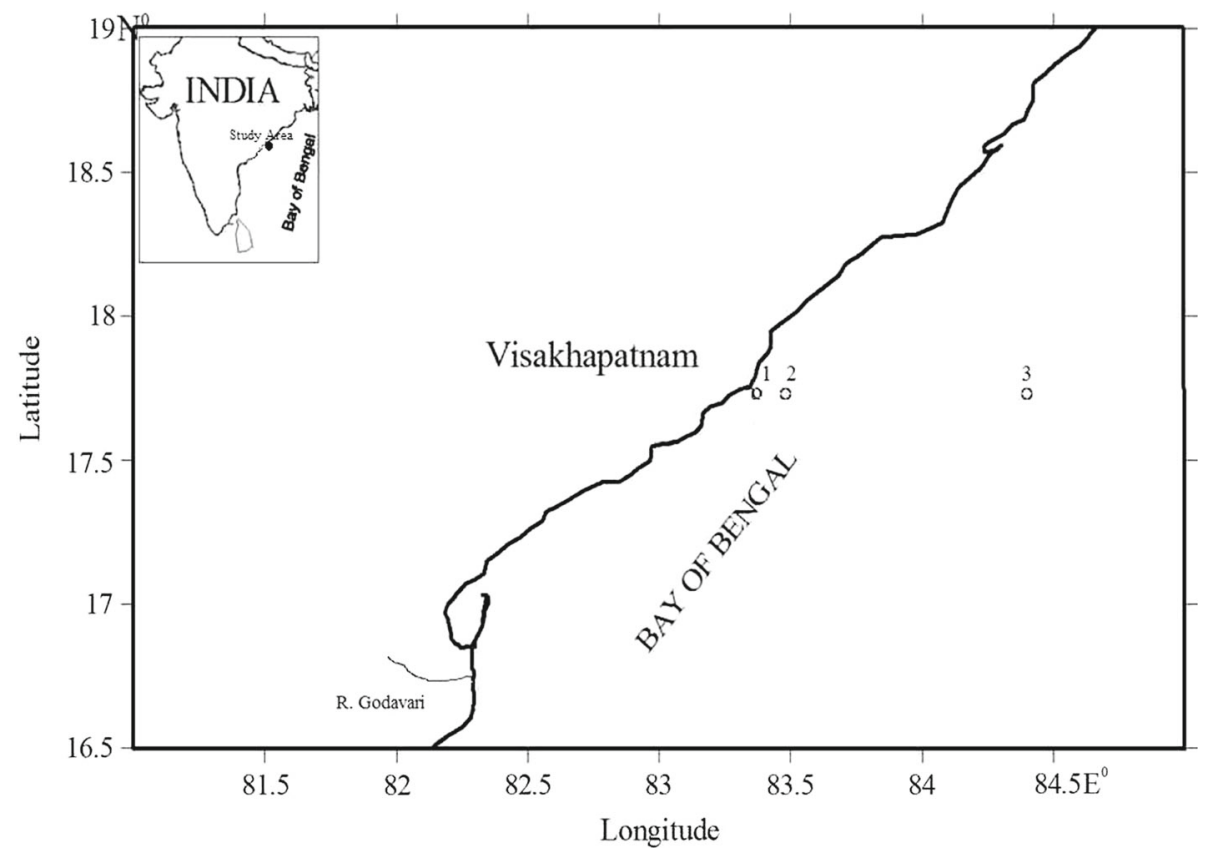

Figure 1. Study area showing stations at different water depths namely, $20 \mathrm{~m}$ (1), $30 \mathrm{~m}$ (2) and $50 \mathrm{~m}$ (3). (At stations 1 and 2, only surface samples were collected once. At station 3, sampling was done at all depths, i.e., surface, $10,20,30$ and $50 \mathrm{~m}$ during each campaign five times in a day, i.e., 8:00, 10:00, 12:00, 14:00 and 16:00 hrs).

\section{Results}

\subsection{Hydrography}

The region is microtidal (tidal range $<1.5 \mathrm{~m}$ during the study period), the tides being semidiurnal. During mid-day (12:00-14:00 hrs) when the solar insolation (and biological production) is at peak, neap tide occurred in June, July, September, and December campaigns, springtide occurred in August, and a transitional tide occurred in October, January and February campaigns (figure 2). Salinity was lowest in October $\left(\sim 22 \times 10^{-3}\right)$ and highest in August (35.35, figure S1). Although the tidal range was only $0.5 \mathrm{~m}$ in August, salinity was in tune with the tide and the tidal excursion (salinity difference between the spring and neap tides, $\left.\Delta_{\text {Salinity }}\right)$ was greatest (2.73), at the surface. Spring tide, however, caused salinity minima at depths. During October also, spring tide produced salinity minima at $10-30 \mathrm{~m}\left(\Delta_{\text {Salinity }}=1.6\right)$ and had no effect at surface. In December, the $\Delta_{\text {Salinity }}$ was the least $(\sim 1.2)$, and a tidal oscillation confined to the upper $10 \mathrm{~m}$ water occurred. During other campaigns, salinity had no relation to tide.

The water column was moderately cooler than at surface and the temperature difference between surface and bottom water $\left(\Delta_{\mathrm{T}}\right)$ was $<2^{\circ} \mathrm{C}$ (figure $\mathrm{S} 1)$. In December, a $2.13^{\circ} \mathrm{C}$ temperature inversion was seen at $20 \mathrm{~m}$ with respect to surface, which is attributed to the surface cooling during winter (December). The effect of intense solar heating is seen in July with $4.5-6.8^{\circ} \mathrm{C}$ heating of the water column as the day progressed. During July, dissolved oxygen was more enriched in surface water (average, $256 \mu \mathrm{M}$ ) as compared to the rest of the campaigns (226). But in the same month (July), dissolved oxygen concentration was among the lowest cf., $\sim 110 \mu \mathrm{M}$ at $50 \mathrm{~m}$ depth, which synchronized with the lowest $\mathrm{pH}$ observed (7.7) in the study (figure S1). There was a steep oxycline, attributed to stability of the water column in July. The concentration of nutrients was low and complex (figure S1). However, with the limited data of nitrate that we had (June, July and August, 2013; range: $0.8-20.4 \mu \mathrm{M})$, phosphate correlated excellently and yielded the relationship: Phosphate $=0.0566 \times$ Nitrate with $R^{2}=0.57(n=75$, $p<0.0001$ ). Chlorophyll a (figure 3a) was also low (range: $0.69-3.41 \mu \mathrm{g} \mathrm{L}^{-1}$ ), and was not related to nutrients.

\subsection{Phytoplankton abundance and distribution}

Phytoplankton belonged to 133 species, mostly of diatoms (Centrics 73; Pennales 22) and less of dinoflagellates (33), blue green (BG) algae (3) and silicoflagellates (2) (table S1). The cell densities were highest for Guinardia delicatula, G. striata and Trichodesmium erythraeum (figure 4) in some 

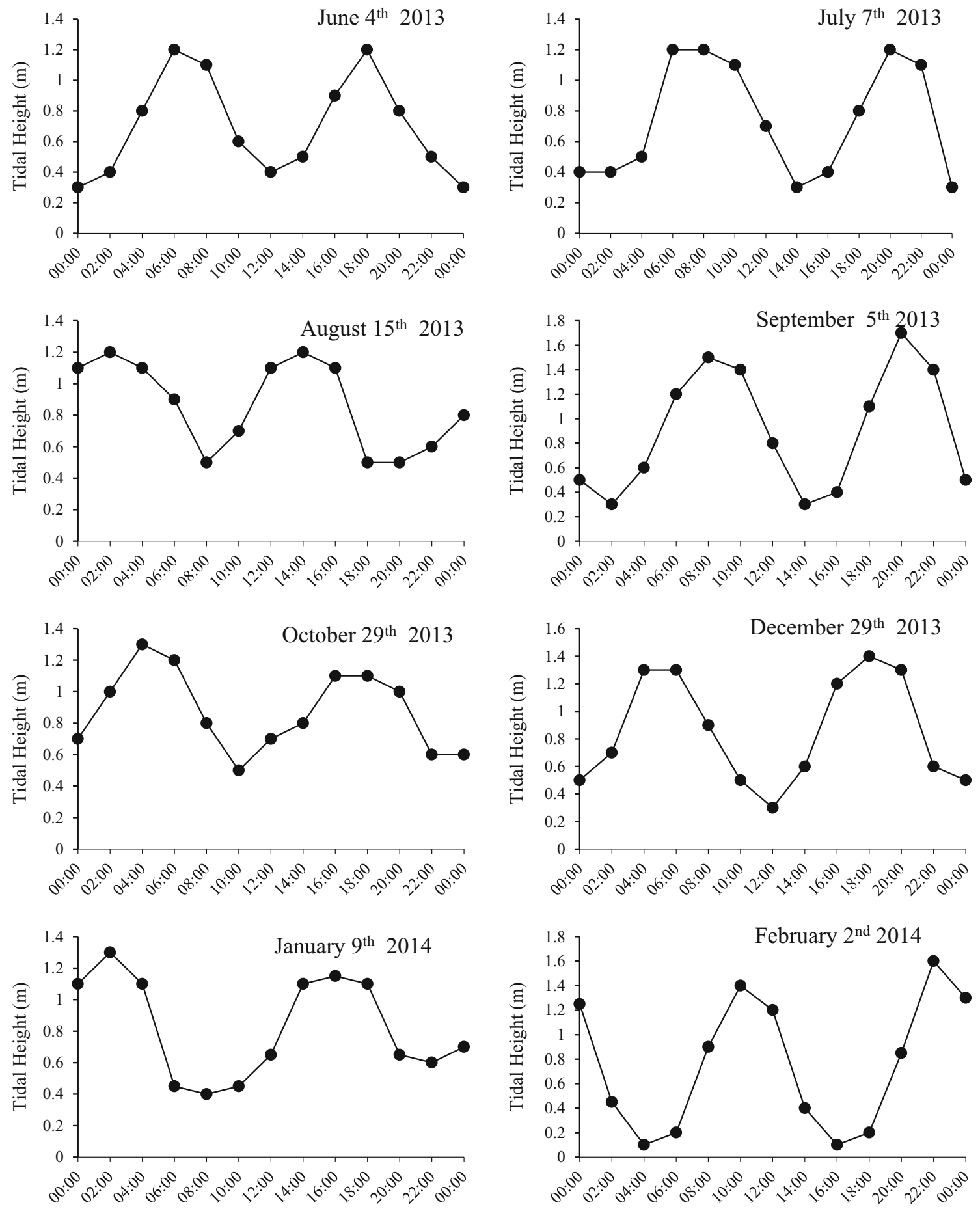

Figure 2. Tidal heights during 24-hr period of the sampling dates (June 2013-February 2014), i.e., from 8 hrs before the beginning of sampling to $8 \mathrm{hrs}$ after the end of each field sampling. (X-axis: (1) 8:00; (2) 10:00; (3) 12:00; (4) 14:00; (5) 16:00 hrs).

samples. The total cell density of dinoflagellates ranged from 0 to $33 \mathrm{ml}^{-1}$ with an average of 4 , and most of the dinoflagellates were not represented in majority of the samples. They were relatively more enriched at surface and the more common species were Ceratium trichoceros, C. furca and Prorocentrum micans.

\subsection{Tidal rhythm of phytoplankton}

Peaks of phytoplankton abundance occurred in July at $10 \mathrm{~m}$ depth (cell count, $2547 \mathrm{ml}^{-1}$ ) and during September and December, at surface (817 and 577, respectively), all at 14:00 hrs. Phytoplankton density (figure 5), and in particular the abundance 
(a) $\mathrm{Chl} \mathrm{a}\left(\mu \mathrm{gL}^{-1}\right)$
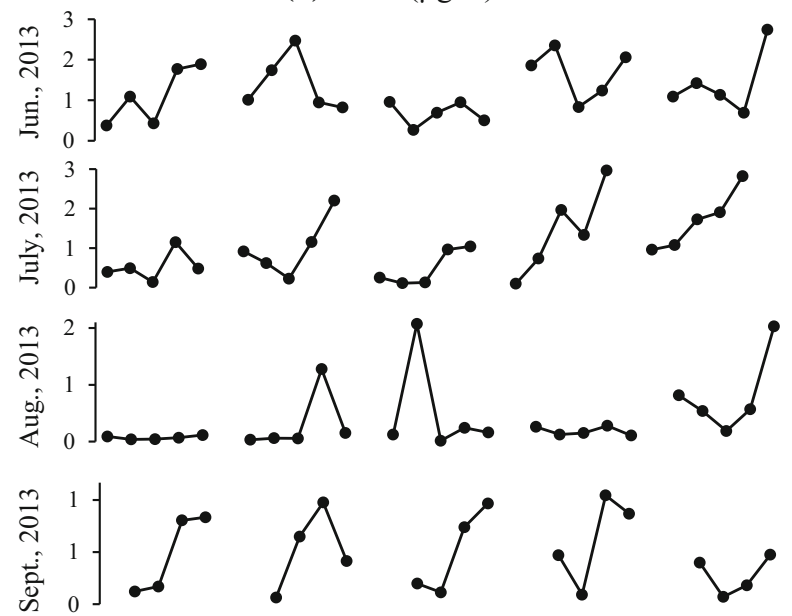

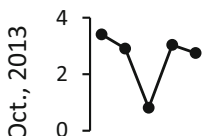
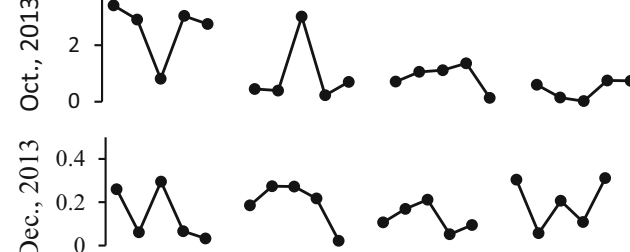

a
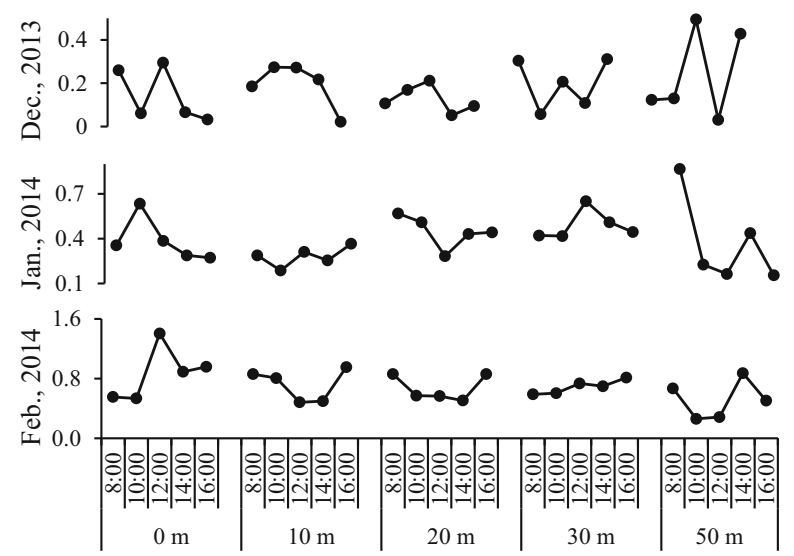

(b) Biovolume $\left(\mathrm{mm}^{3} \mathrm{ml}^{-1}\right)$
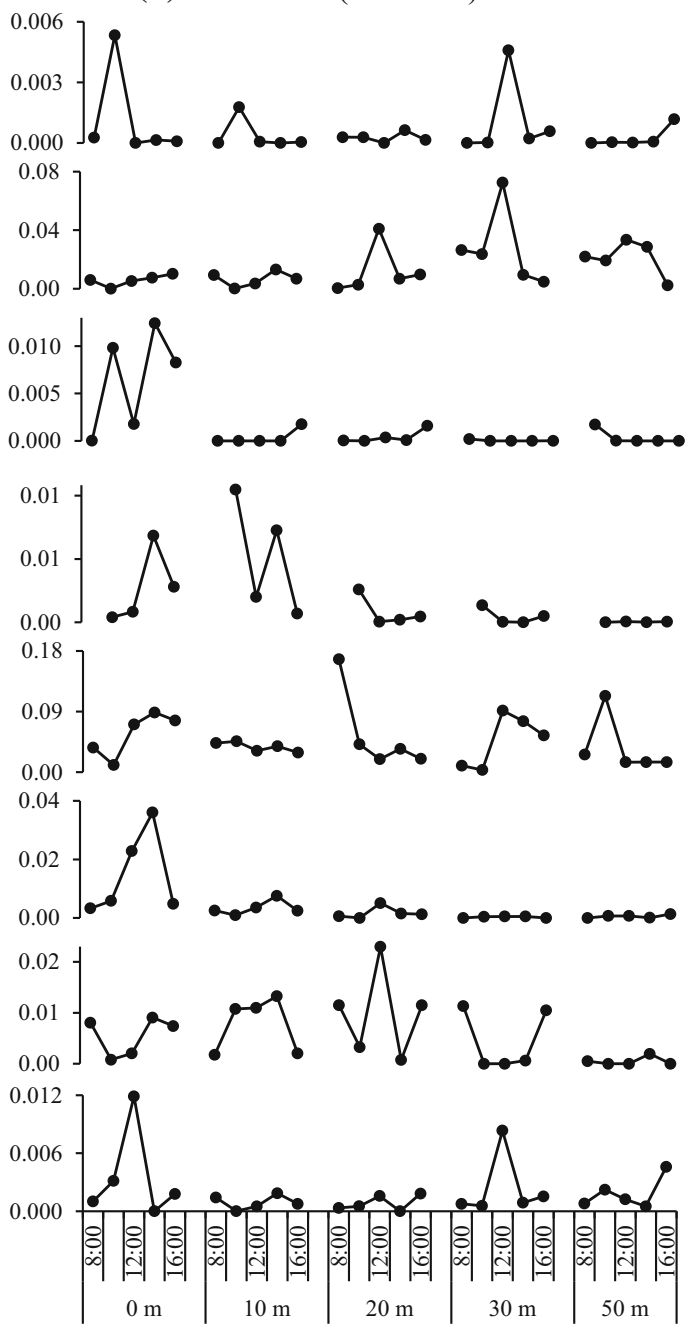

Figure 3. Time series concentrations of (a) chlorophyll $a$ and (b) total phytoplankton biovolume in the water column during the 8 field campaigns at different depths of the water column (note: there were no observations at 8:00 hrs in September).

of Guinardia delicatula (figure 5a) synchronized with tide, the maxima and minima occurring at the neap and spring tides respectively at all depths in the water column during July, and in the upper $10 \mathrm{~m}$ water column during September and December. In October, the cell count was reasonably high (average, $274 \mathrm{ml}^{-1}$ ), but chlorophyll $a$ among the highest $\left(2.6 \mu \mathrm{g} \mathrm{L}^{-1}\right)$ in the upper $10 \mathrm{~m}$ water (figure 3a). Thalassionema nitzschioides, Thalassiothrix frauenfeldii and Pseudonitzschia seriata contributed majorly (up to $71 \%$, figure S1), and there was no tidal rhythm in their distribution. During June, despite neap tide occurrence at noon, and during other campaigns (months) in which the neap tide occurred at other times during the day (August, January and February), no such oscillations were shown.
Guinardia delicatula constituted a predominant fraction of total phytoplankton cell count at $10 \mathrm{~m}$ $(92 \%)$ (table 1) followed by surface $(82 \%)$ and $20 \mathrm{~m}(65 \%)$ during July at neap tide. Remarkably, G. striata representation in the cell count was also high and synchronized with neap tide, but its peak representation in phytoplankton was confined to the 20-30 m water layer (4\%-10\%). During September too, G. delicatula showed tidal rhythm and its representation (to phytoplankton) was highest at neap tide but at surface (64\%) (table 1). G. striata represented less to phytoplankton at its peak at $10 \mathrm{~m}$ at neap tide (35\%). In December, T. erythraeum represented dominantly the phytoplankton cells, close to neap tide, at surface (82\%). The next major species was Oscillatoria sp. (11\%), also a diazotroph. At $10 \mathrm{~m}$, however, majority 

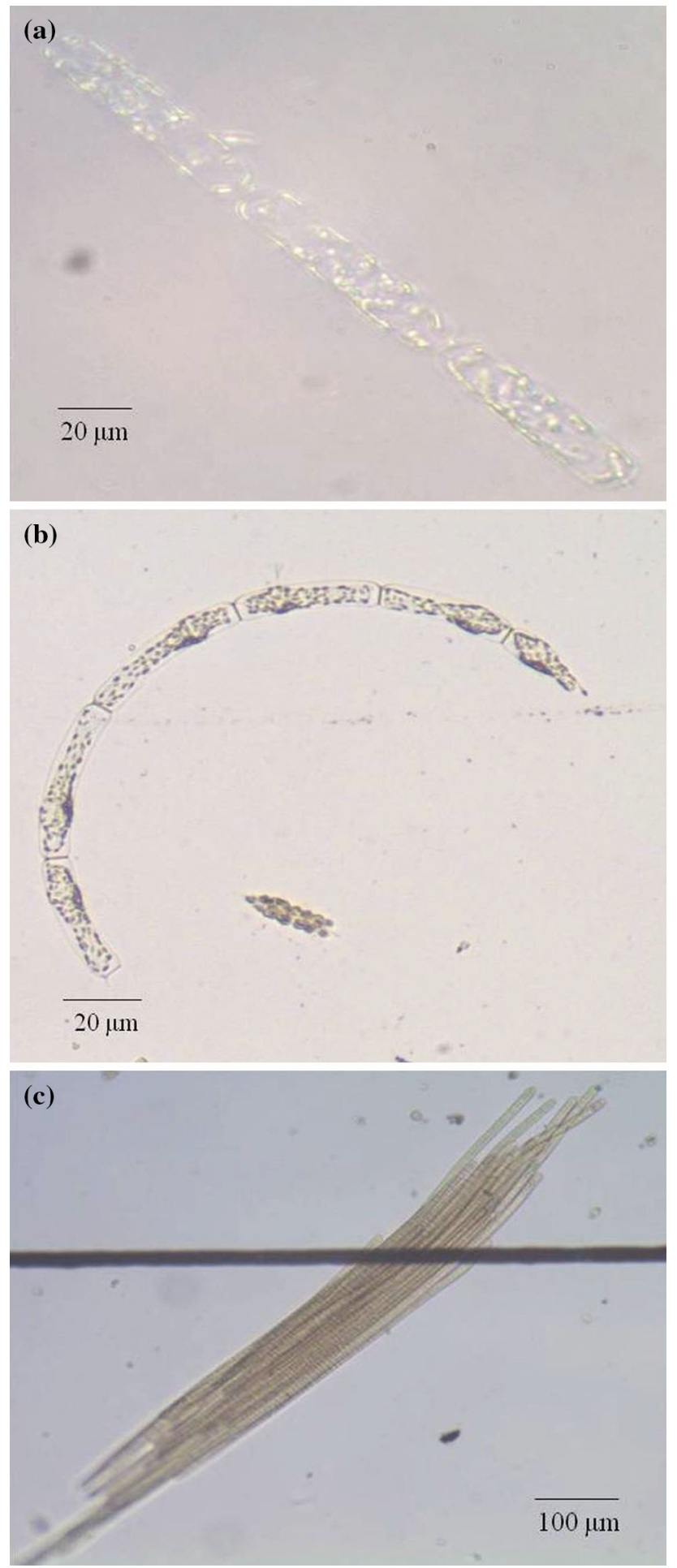

Figure 4. Typical microscopic images at $\times 10$ magnification: (a) Guinardia delicatula (3 cells in chain), (b) Guinardia striata (6 cells) in July samples and (c) Trichodesmium erythraeum bundle in December samples.

were centric diatoms (24\%), in which G. delicatula $(19 \%)$ and Bacteriastrum delicatulum (17\%) were the better represented (table $\mathrm{S} 1$ ).
3.4 Phytoplankton bio-volume and its relationship to chlorophyll ' $a$ '

From the phytoplankton cell shapes and dimensions as viewed under the microscope, the average of $3-5$ representative cells of each species of all campaigns, equivalent spherical diameter (ESD) and average cell bio-volume (BV) were computed, using standard methods (Hillebrand et al. 1999; Sun and Liu 2003) (figure 3b). The ESD and BV varied inter-species by factors of 24 and 14,000, respectively from the largest $R h i$ zosolenia robusta (table 1 ) to the smallest Thalassionema nitzschioides (table 2). G. delicatula is smaller than $G$. striata and T. erythraeum (table 1).

The total phytoplankton BV is highest in October and reached $0.171 \mathrm{~mm}^{3} \mathrm{ml}^{-1}$ at $20 \mathrm{~m} \mathrm{(08:00} \mathrm{hrs)}$ when chlorophyll $a$ was also high (figure $3 \mathrm{~b}$ ). This was despite the fact that the cell density was low at surface (average, $\sim 370 \mathrm{ml}^{-1}$ ) (table $\mathrm{S} 1$ ). The phytoplankton distribution in this month consisted of mainly diatoms Thalassiothrix fraunfeldii (average, 31\%), Skeletonema costatum (19\%), Ditylum sol and Thalassionema nitzschioides (12\% each), Chaetoceros curvisetus (11\%), Odontella sinensis $(9 \%)$ and $O$. mobiliens $(6 \%)$ (table S1). To the $\mathrm{BV}$, the larger cell sized species namely $D$. sol, O. sinensis and O. mobiliens contributed as much as $60-100 \%$ (average $\pm \mathrm{SD}, 85 \pm 11 \%, n=$ $25)$. In July, when the phytoplankton (G. delicatula) density was the highest, $G$. delicatula constituted as much as $92 \%$ of cell density but its contribution to BV was only $21.1 \%$ at 10 $m$ depth (table 1). Considering the Rhizosoleniaceae family of species, the cell density increased marginally to $95.3 \%$ (table 1), but their BV contribution shot up to $76.8 \%$ (data not shown) due to the large cell sized species such as Rhizosolenia robusta.

The BG algae contribution to total phytoplankton BV was high in December, January and February. In December, when the tidally rhythmic T. erythraeum cells dominated at surface, the contribution was $82 \%$ (table 1).

The graph of cell density or BV against chlorophyll $a$ was highly scattered. On the other hand, the cell density related to BV when they were less than $\sim 800$ cells $\mathrm{ml}^{-1}$ (i.e., excepting in July) and $0.07 \mathrm{~mm}^{3} \mathrm{ml}^{-1}$ (excepting in October) respectively (figure 6a). The coefficient of determination $\left(R^{2}\right)$ was moderately high $(0.38)$ but it is highly significant $(p<0.0001)$ in view of the large sample 

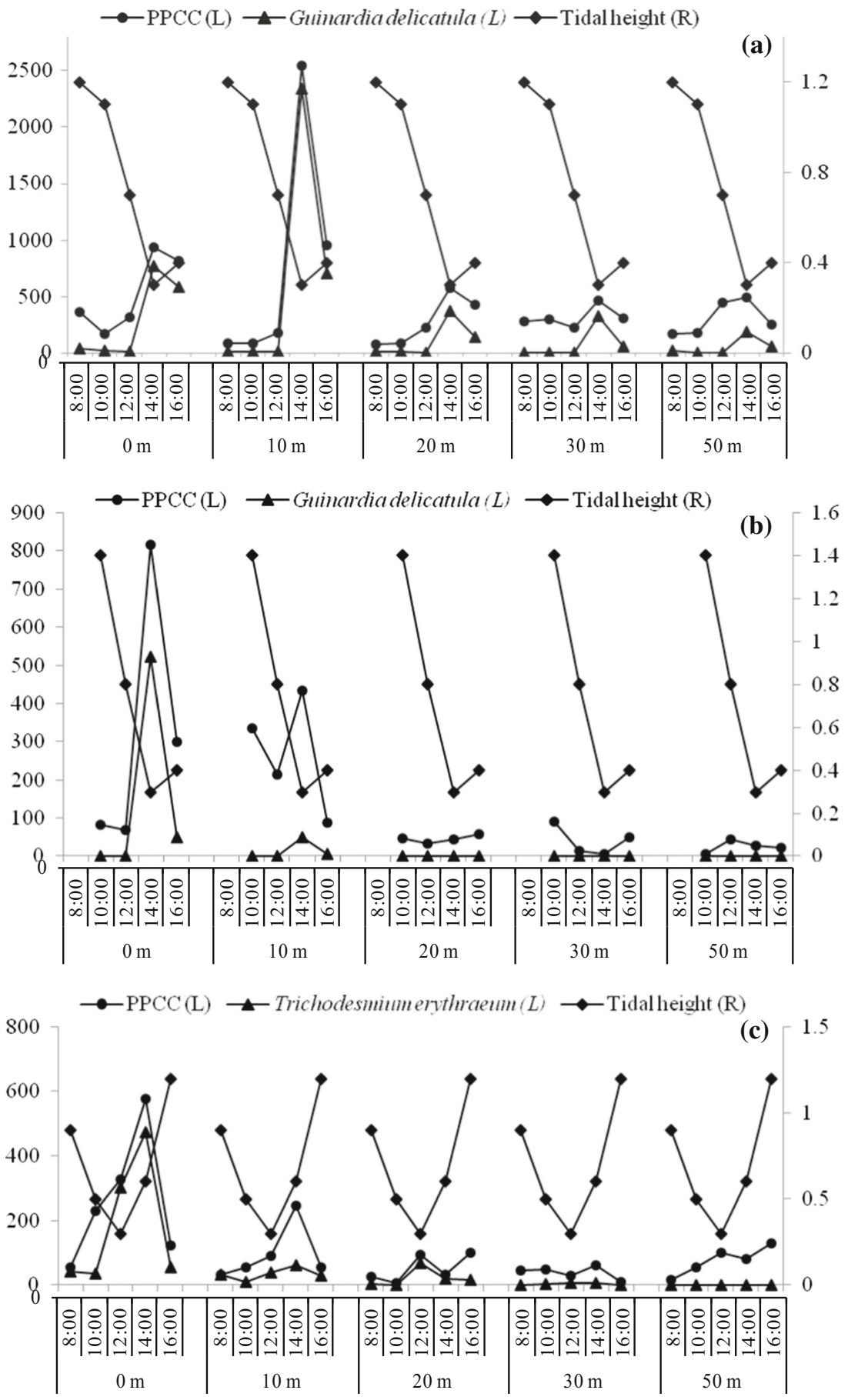

Figure 5. Diurnal variation in the water column of phytoplankton cell count (PPCC, left, L), and of G. delicatula abundance (L) in July (a) and September (b), and of Trichodesmium erythraem abundance (L) in December (c), overlaid on tidal height (right, R) (X axis, 1: 08:00 hr, 2: 10:00 hr, 3:12:00 hr, 4: 14:00 hr and 5: 16:00 hr). Units: Left axis (L): cells ml ${ }^{-1}$, Right axis $(\mathrm{R})$ : meters.

size $(n=238)$. In this group of samples, there is a slightly weaker (negative) correlation of $\mathrm{BV}$ with salinity $\left(R^{2}=0.32, n=238\right)$ and this relation also is highly significant $(p<0.0001)$. The BV of phytoplankton rich samples (PPCC $>800$ cells $\mathrm{ml}^{-1}$ ) is aligned with the regression line as shown (figure 6b).

\section{Discussion}

The biogeochemistry of the region agrees with previous reports (Chari et al. 2012, 2013b; Pandi et al. 2014). The significant relationship between nitrate and phosphate yields N:P ratio of $17.85: 1$ which is close to the Redfield ratio (16:1) and infers that 
Table 1. Species distribution during the phytoplankton cell count (CC) maxima and their average at neap tide (14:00 hrs) during July, September and December campaigns and their average equivalent spherical diameter (ESD, $\mu m$ ) (significant species only, cell count>2).

\begin{tabular}{|c|c|c|c|c|c|c|c|}
\hline \multirow[b]{2}{*}{ Species name } & \multicolumn{2}{|c|}{ July $(17)^{*}$} & \multicolumn{2}{|c|}{ September $(16)^{*}$} & \multicolumn{2}{|c|}{ December $(5)^{* *}$} & \multirow{2}{*}{$\begin{array}{l}\mathrm{ESD}^{\#} \\
(\mu \mathrm{m})\end{array}$} \\
\hline & $\mathrm{CC}$ & $\mathrm{CC}(\%)$ & $\mathrm{CC}$ & $\mathrm{CC}(\%)$ & $\mathrm{CC}$ & $\mathrm{CC}(\%)$ & \\
\hline \multicolumn{8}{|l|}{ Centric Diatoms } \\
\hline Bacteriastrum furcatum & - & - & 13 & 1.6 & - & - & 11.2 \\
\hline Chaetoceros curvicsetus & 7 & 0.3 & - & - & - & - & 16.6 \\
\hline Chaetoceros coarctatus & - & - & - & - & 30 & 5.2 & 26.1 \\
\hline Chaetoceros lorenzianus & - & - & 3 & 0.4 & - & - & 49.4 \\
\hline Chaetoceros sp. & - & - & 13 & 1.6 & - & - & $\#$ \\
\hline Corethron sp. & - & - & 3 & 0.4 & - & - & $\#$ \\
\hline Guinardia delicatula & 2343 & 92.5 & 523 & 64.1 & - & - & 19.7 \\
\hline Guinardia striata & 33 & 1.3 & 107 & 13.1 & - & - & 46.2 \\
\hline Hemiaulus hauckii & - & - & 10 & 1.2 & - & - & $\#$ \\
\hline Hemiaulus sinensis & - & - & 3 & 0.4 & - & - & 27.3 \\
\hline Leptocylindrus sp. & - & - & 13 & 1.6 & - & - & \# \\
\hline Odontella aurita & 10 & 0.4 & - & - & - & - & 50 \\
\hline Odontella mobiliensis & 7 & 0.3 & - & - & - & - & 82.3 \\
\hline Rhizosolenia crassispina & - & - & 3 & 0.4 & - & - & 84.9 \\
\hline Rhizosolenia imbricata & 17 & 0.7 & - & - & - & - & 27.3 \\
\hline Rhizosolenia hyalina & - & - & 3 & 0.4 & - & - & $\#$ \\
\hline Rhizosolenia pungens & 23 & 0.9 & 3 & 0.4 & - & - & 51.2 \\
\hline Rhizosolenia robusta & 7 & 0.3 & - & - & - & - & 183.1 \\
\hline Rhizosolenia setigera & 3 & 0.1 & - & - & - & - & 36.7 \\
\hline Rhizosolenia styliformis & - & - & 23 & 2.9 & - & - & $\#$ \\
\hline \multicolumn{8}{|l|}{ Pennate diatoms } \\
\hline Asterionella japonica & - & - & 33 & 4.1 & - & - & 21.1 \\
\hline Climacosphenia moniligera & 3 & 0.1 & - & - & - & - & 136.8 \\
\hline Cylindrotheca closterium & - & - & - & - & 3.33 & 0.6 & 19.5 \\
\hline Navicala sp. & 7 & 0.3 & - & - & - & - & 55.9 \\
\hline Nitzschia sp. & 13 & 0.5 & - & - & - & - & 19 \\
\hline Pleurosigma sp. & 7 & 0.3 & - & - & - & - & 74.8 \\
\hline Pseudonitzschia pungens & 40 & 1.6 & - & - & - & - & 11.9 \\
\hline Thalassiothrix longissima & 7 & 0.3 & 53 & 6.5 & - & - & 20.8 \\
\hline \multicolumn{8}{|l|}{ Cyanobacteria } \\
\hline Oscillatoria sp. & - & - & - & - & 66.7 & 11.6 & 19 \\
\hline Trichodesmium erythraeum & - & - & - & - & 473 & 82.0 & 52.6 \\
\hline \multicolumn{8}{|l|}{ Dinoflagellates } \\
\hline Ceratium furca & 3 & 0.1 & - & - & - & - & $\#$ \\
\hline Ceratium gibberum & - & - & - & - & 3.33 & 0.6 & $\#$ \\
\hline Prorocentrum micans & 3 & 0.1 & - & - & - & - & $\#$ \\
\hline Peridinium sp. & - & - & 7 & 0.8 & - & - & \# \\
\hline Total (all species) & 2533 & 100 & 817 & 100 & 577 & 100 & \\
\hline Total (Rhizosoleniaceae) & 2427 & 95.3 & 663 & 81.2 & 0 & 0 & \\
\hline
\end{tabular}

Water depths: ${ }^{*} 10 \mathrm{~m} ;{ }^{* *}$ surface; ${ }^{\#}$ data not available.

the waters of June-August (for which the data were available) are mainly of oceanic origin (Chiranjeevulu et al. 2014), and there was no significant input of nutrients through terrestrial flux. The low salinity of October, however, is attributed to intense monsoon activity and dilution by the east India coastal current (Shankar et al. 2002).

\subsection{Cell number-total bio-volume-chlorophyll mismatch}

The calculated bio-volumes of different species agree broadly with those reported in other ecosystems, e.g., the Baltic (Olenina et al. 2006) and the northern Arabian Sea (Naz et al. 2013). In 
Table 2. Average cellular equivalent spherical diameter (ESD, $\mu \mathrm{m}$ ) during non-PPCC maxima of significant (cell count>2) phytoplankton species (contd. from table 1).

\begin{tabular}{lr}
\hline Species & ESD \\
\hline Asteromphalus sp. & 52.8 \\
Bacteriastrum comosum & 19.8 \\
Bacteriastrum hyalinum & 23.6 \\
Chaetoceros affinis & 23 \\
Chaetoceros atlanticus & 22.1 \\
Chaetoceros borealis & 17.9 \\
Chaetoceros compressus & 23 \\
Chaetoceros constrictus & 16.6 \\
Coscinodiscus asteromphalus & 90.1 \\
Coscinodiscus excentricus & 32.1 \\
Coscinodiscus radiatus & 33.1 \\
Coscinodiscus sp. & 48.1 \\
Ditylum brightwelli & 99.7 \\
Ditylum sol & 135.4 \\
Leptocylindrus danicus & 21.1 \\
Melosira sp. & 44.8 \\
Melosira moniliformis & 32.9 \\
Odontella sinensis & 181.7 \\
Rhizosolenia alata & 88.3 \\
Skeletonema costatum & 13.5 \\
Thalassiosira sp. & 17.1 \\
Nitzschia longissima & 23.1 \\
Pseudo-nitzschia seriata & 19.8 \\
Thalassionema nitzschioides & 7.9 \\
Thalassiothrix frauenfeldii & 9.4 \\
Crorocentrum micans & 19 \\
Ceratium furca &
\end{tabular}

the study area, besides microplankton, nano and picoplankton constitute sizable fractions of the phytoplankton consortia (Pandi et al. 2014), and the fact that they have not been accounted, may explain partially the mismatch. The mismatch is also explained on the basis that a strict correspondence of chlorophyll $a$ with bio-volume will happen only when the bio-volume-specific chlorophyll $a$ is constant, i.e., in the case of monospecific species at a constant irradiance level (Hitchcock 1980) and physiological state (Sathyenranath et al. 2009).

\subsection{G. delicatula tidal rhythm}

It is now recognized that tides can control phytoplankton distribution in estuaries (Cloern 1991; Lucas et al. 1999; Trigueros and Orive 2000) and in shallow coastal macrotidal regions of the coastal sea (Blauw et al. 2012; Houliez et al. 2013). Some species showed tidal flushing, some tidal enrichment and some were little affected in estuary (Cloern 1991). The dinoflagellate Peridinium quinquecorne showed movement to the near-surface layer during intense sunlight, but only during the incoming tide (Horstmann 1980). But tidal oscillations have not been reported in microtidal, shelf regions. Momentary bloom promotion in the coastal zone due to pycnocline outcropping at surface and vertical advection of nutrient-rich waters forced by energetic inertial current oscillations due to diurnal wind variability has been observed (Lucas et al. 2013). The photosynthetic potential $\left(P_{\max }\right)$ is maximal at mid-day, and the available reports do not record greater than $10 \mathrm{x}$ enrichment of phytoplankton $P_{\max }$ with reference to the pre-dawn value (Prezelin et al. 1987).

In the present study, enrichment at neap tide during July (14:00 hrs) was by a factor of 29 for total phytoplankton and 234 for G. delicatula relative to the cell count at 8:00 hrs at $10 \mathrm{~m}$ depth. The corresponding enrichment factors at surface were 2.6 and 20.8, respectively. The enrichments should be expected to be even higher with respect to pre-dawn cell count, data of which are not available. Nutrient enrichment induced by diel changes in winds (Lucas et al. 2013) and deep water entrainment by internal waves (Prairie et al. 2012) is ruled out since winds were subdued and silicate decreased correspondingly from 2.59 to $1.03 \mu \mathrm{M}$ and from 2.45 to $1.08 \mu \mathrm{M}$ at surface and phosphate showed only marginal increase (from 0.26 to $0.38 \mu \mathrm{M}$ at surface and from 0.26 to 0.28 at $10 \mathrm{~m}$, respectively) at the time (figures $\mathrm{S} 1 \mathrm{e}, \mathrm{f}$ ). For the domination of $G$. delicatula in the phytoplankton assemblage, different types of fronts (Franks 1992) as possible causes are ruled out as the tidal range is small, sea floor is not steep sloping, there are no topographic barriers on the seafloor, and because of this, no distinct water masses could be recognized.

The negative linear relationship of phytoplankton biomass (bio-volume) with salinity (figure 5b) cannot be attributed to a possible nutrient dilution as nutrients were not related to salinity. It may, on the other hand, indicate a role for tides which cause oscillations in salinity and thereby redistribute the plankton biomass. This influence would not have been visible if only cell densities (and not bio-volume) were considered. In the case of $G$. delicatula (and G. striata to some extent) when they were present in large numbers, the neap tide was accompanying. Other species or even 

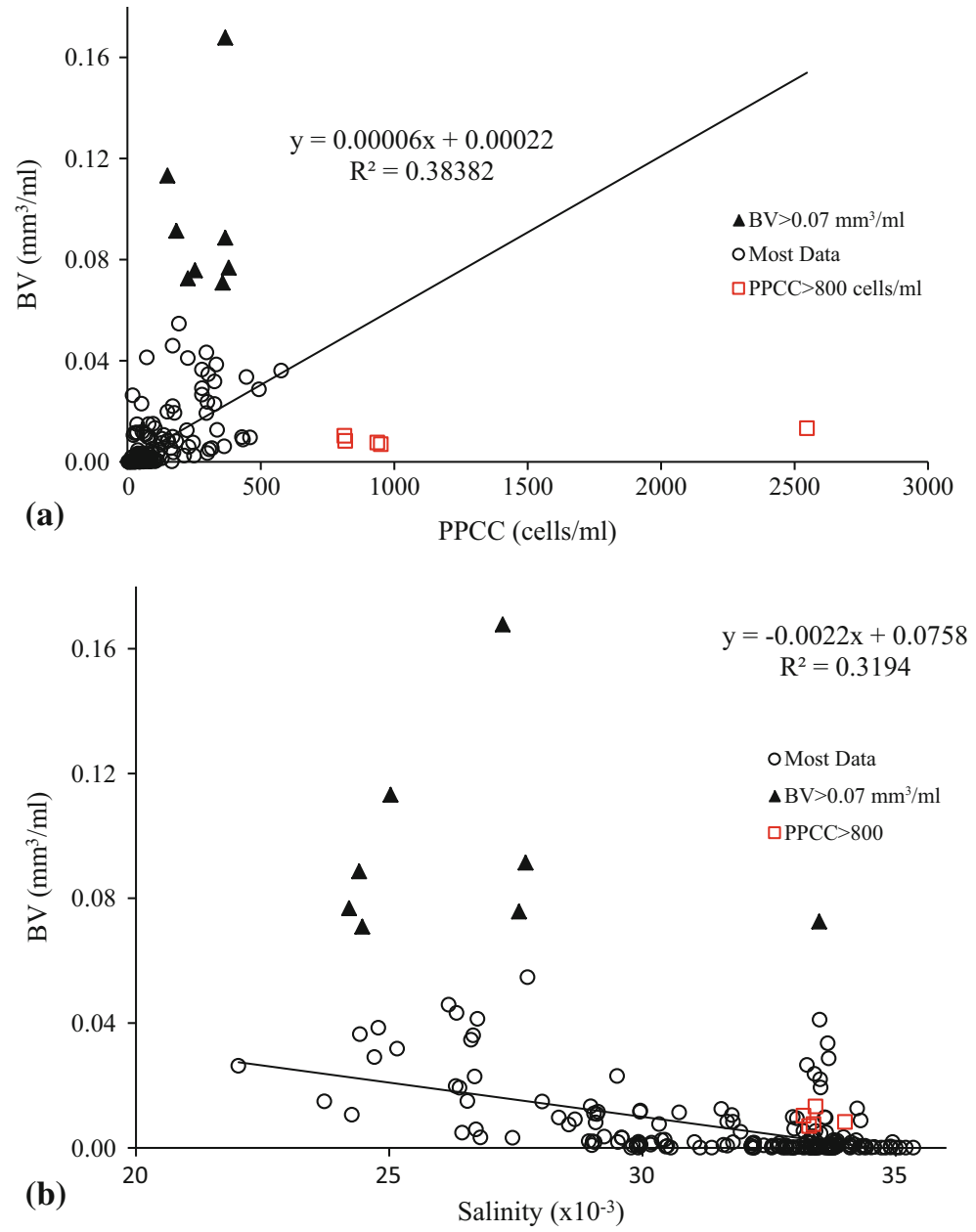

Figure 6. Plots of total phytoplankton bio-volume (BV) vs. (a) Total cell density (PPCC) and (b) salinity.

G. delicatula itself when it was present in lower abundance did not follow the tidal rhythm. Thus $G$. delicatula population is likely an aggregateformed when the cell density exceeded a critical value. High-light-low-nutrient condition promotes aggregate formation via acceleration of transparent exopolymeric particles (TEP) release from algae (Mari and Kiorboe 1996), when the algal production has nearly exhausted the nutrients (Decho 1990) and solar insolation is at maximum. Silicate stress leads to loss of setae, thinning of the valves, increase of carbon cell quota, release of increased amounts of dissolved organic carbon (DOC) and increase in sinking rates (Flynn and Jézéquel 2000). As a proxy for DOC of in situ source, the intensity of tryptophan protein-like fluorescence $(\mathrm{T})$ peak was measured as described in Chari et al. (2012). It was highest during July $\left(8.91 \times 10^{-3}\right.$ Raman Units), among all sampling campaigns, in the upper $10 \mathrm{~m}$ water (our unpublished results). This was despite the fact that chlorophyll $a$ (phytoplankton), considered the source of the $\mathrm{T}$ peak was not correspondingly high $\left(0.78 \mu \mathrm{g} \mathrm{L}^{-1}\right.$, figure $\left.3 \mathrm{a}\right)$.

\subsubsection{Bloom mechanism}

When the tide was receding, phytoplankton of the coastal region drifts along the tidal current into the sea. As the tide was to return from the lowest level, the tidal amplitude being low $(0.8 \mathrm{~m})$, a gentle and steady physical forcing is established which causes zonation of the pre-existing phytoplankton ( $G$. delicatula), aided by the solar insolation maxima. The zonation likely occurred closer to the time series station than the stations nearer the coast as the $G$. delicatula (phytoplankton) abundance decreased towards the shore at surface (St. 1 and St. 2, figure 1) during our return after the last timeseries collection at 16:00 hrs (table S1).

Ergoclines are sharp transition zones between high and null (or low) tidal energies of estuaries and estuary affected coastal regions in which regions of increased biological production are formed, as 
a result of the matching or resonance of physical scales with biological scales (Legendre et al. 1986; Ragueneau et al. 1996). The ergoclines so far investigated are of macrotidal regions. However, the present region is microtidal. Moreover, the cell densities of $G$. delicatula and $G$. striata reached maxima at 14:00 hrs during all summer samples irrespective of whether the neap tide was co-occurring or not (table S1). Ecological factors constitute the basic requirement, and the physical factors (tide) the trigger for the formation of the transient phytoplankton bloom.

We also performed, but on dates different from the present, time series measurements at $100 \mathrm{~m}$ bathymetric station, $60 \mathrm{~km}$ away from the coast, and $45 \mathrm{~km}$ offshore of station 3 (not shown in figure 1). The phytoplankton composition was completely different between that station and St. 3. In December 2013 and February 2014, phytoplankton cell densities were high $\left(\sim 600\right.$ cells $\left.\mathrm{ml}^{-1}\right)$, dominated by the pinnate diatom Achnanthes brevipes (84\%) and Trichodesmium erythraeum (94\%) respectively at the offshore station. G. delicatula was not represented, although $G$. striata did appear as a minor constituent (3-20 cells $\mathrm{ml}^{-1}$; our unpublished results), thus ruling out offshore water as possible source of the coastal (St. 3, figure 1) phytoplankton (bloom) and vice versa.

The fraction of $G$. delicatula representing phytoplankton was lower at $>10 \mathrm{~m}$ depth, and heavier celled taxa increased correspondingly. Down the water column, microbial exudates and binding material are increasingly decomposed by bacteria (Chow and Azam 1988) which results in weakening of adhesion in clusters of the aggregate. The occurrence of a deeper $(20 \mathrm{~m})$ maximum for G. striata (table S1) suggests that the mucilaginous TEP released by this species is likely less labile/preferred by bacteria than the TEP released by $G$. delicatula. The occurrence of $G$. delicatula bloom in a tropical sea, in the mid-summer, and at a lower level of abundance during the summer monsoon (September) raises questions regarding its adaptation. But more basically, the study points to the possibility that the earlier studies had missed the ambient concentrations due to dependence of $G$. delicatula abundance in the ecosystem on tide.

\subsection{Winter maximum of Trichodesmium erythraeum}

The alga is suspected to cause fish mortality by asphyxiation through gill damage by the algal filaments (Satpathy et al. 2007). Trichodesmium blooms are rarely reported, most of them during spring (Ramamurthy et al. 1972; Santhanam et al. 1994; Jyothibabu et al. 2003; Mohanty et al. 2010; Sahu et al. 2012), lasting for a day or two in the Bay of Bengal (Satpathy et al. 2007; Hegde et al. 2008; Shetye et al. 2013), and rarely in winter monsoon (Vinayachandran and Mathew 2003). Weak winds and water column stability, favourably disposed in the winter season are favourably factors for the Trichodesmium blooms (Madhu et al. 2006). The occurrence of T. erythraeum maximum at 14:00 hrs, instead of 12:00 hrs when the neap tide occurred (figure 5c) may indicate that a lag likely results from the larger size of bundles of the algal trichomes requiring a greater 'push' by the tide than in the case of $G$. delicatula.

The study terminated (after February 2014), before the onset of spring, but the distribution spread over the preceding 8 months does indicate that it is likely that the blooms at other times of the year were not captured because of the diurnal (i.e., tidal) component. We did not observe tidal rhythm during June, August, October, January and February campaigns, and attribute it to: (i) low phytoplankton abundance due to seasonal factors, (ii) phytoplankton was more constituted of nano- and pico-plankton that did not show the oscillation, (iii) turbulent water due to currents and wind, and (iv) the neap tide not occurring during mid-day.

\subsection{Concerns associated with G. delicatulatransient bloom}

G. delicatula blooms have not so far been reported from tropical regions. The maximum relative abundance reported in a tropical sea is $<14 \%$ of the total phytoplankton, in the eastern Arabian Sea (Hegde et al. 2008). It is more commonly reported in the sub-tropical and sub-polar waters in which the blooms take place in late spring to early summer. Blooms of $G$. delicatula in the Indian coastal waters is of ecological concern as unialgal blooms of $G$. delicatula are believed to clog the gills of shell fish to the extent of inhibiting their growth (Lorrain et al. 2000) and because the alga is suspected to be a source of the toxic arsenic (III) and methylated arsenic (Howard et al. 1995).

The role exercised by hydrodynamics in facilitating the formation of a transient, short lived bloom offers both opportunities and challenges in remote estimation of chlorophyll $a$ as blooms caused by 
tidal oscillations are likely missed by the satellites if their pass is not synchronizing. The phytoplankton aggregates since then have higher sinking rates, enrich the food resource in the benthic region (Nascimento et al. 2008), implying higher fishery potential. A faster export and burial of carbon on the seafloor will also result in increased carbon sequestration (Laurenceau-Cornec et al. 2015).

\section{Conclusion}

The study investigated the influence of hydrodynamic factors, in particular tides, in addition to the hydrochemical and hydrobiological factors on phytoplankton bloom development in the western Bay of Bengal. The study strongly indicates the influence of tides on species distribution and zonation in the microtidal coastal region. Blooms of Guinardia delicatula, a sub-tropical diatom are reported for the first time from a tropical sea. Its summer bloom at $10-20 \mathrm{~m}$ depth of the coastal region is attributed to a neap tide synchronizing with solar insolation maxima, weak winds and a stable water column. The station where the diel observations were made likely was occupied by the tidal front which could favour zonation of the pre-existing cells to a transient bloom. The bloom likely was as aggregate as its formation and was probably aided by transparent exopolymer particles released due to nutrient exhaustion and intense solar radiation. The bloom dissipated as quickly as it formed, and its high resolution dynamics could not be captured due to the limited number of diel observations.

The tidal rhythm, also shown by the taxonomically related $G$. striata (in summer, at depth) and the unrelated cyanophyte Trichodesmium erythraeum (in winter, at surface) supports the role of tides in zonation of these species. The bio-volume (and not cell density) captures, weakly though, the association between total phytoplankton and the stage of the tide (salinity). As the tidally driven zonation of phytoplankton is transient, it is most likely not captured by remote sensing satellites. The faster sinking rates associated with the aggregates of phytoplankton formed during bloom may mean a more efficient biological pump.

\section{Acknowledgements}

Authors are grateful to the Director, National Institute of Ocean Technology (NIOT, Chennai) for the coastal research vessel (CRV Sagar
Paschimi) and the captains, other crew members and Mr. T Babu, Technical Assistant for cooperation during the cruises. Financial assistance from the Indian National Centre for Ocean Information Services (INCOIS/093/2007 and INCOIS:F\&A: XII:D2:023), and the Council of Scientific and Industrial Research (CSIR/21(0802)/10/EMR-II) are gratefully acknowledged.

\section{References}

Blauw A N, Beninca E, Laane R W P M, Greenwood N and Huisman J 2012 Dancing with the tides: Fluctuations of coastal phytoplankton orchestrated by different oscillatory modes of the tidal cycle; Plos One 7(11) e49319, doi: 10.1371/journal.pone.0049319.

Chari N V H K, Sarma N S, Pandi S R and Murthy K N 2012 Seasonal and spatial constraints of fluorophores in the midwestern Bay of Bengal by PARAFAC analysis of excitation emission matrix spectra; Estuar. Coast. Shelf Sci. 100 162-171.

Chari N V H K, Keerthi S, Sarma N S, Pandi S R, Chiranjeevulu G, Kiran R and Uma Devi K 2013a Fluorescence and absorption characteristics of dissolved organic matter excreted by phytoplankton species of western Bay of Bengal under axenic laboratory condition; J. Exp. Mar. Biol. Ecol. 445 148-155.

Chari N V H K, Sudarsana Rao P and Sarma N S 2013b Fluorescent dissolved organic matter in the continental shelf waters of western Bay of Bengal; J. Earth Syst. Sci. 122 1325-1334.

Chiranjeevulu G, Narasimha Murty K, Sarma N S, Kiran R, Chari N V H K, Pandi S R, Venkatesh P, Annapurna C and Nageswara Rao K 2014 Colored dissolved organic matter signature and phytoplankton response in a coastal ecosystem during mesoscale cyclonic (cold core) eddy; Mar. Environ. Res. 98 49-59, doi: 10.1016/j.marenvres. 2014.03.002.

Chow B C and Azam F 1988 Major role of bacteria in biochemical fluxes in the ocean's interior; Nature 332 441-443.

Cloern J E 1991 Tidal stirring and phytoplankton bloom dynamics in an estuary; J. Mar. Res. 49 203-221.

D'Silva M S, Anil A C, Naik R K and D'Costa P M 2012 Algal blooms: A perspective from the coasts of India; Nat. Hazards 63 1225-1253.

Decho A W 1990 Microbial exopolymer secretions in ocean environments: Their role(s) in food web and marine processes; Oceanogr. Mar. Biol. Rev. 28 73-153.

Flynn K J and Jézéquel V M 2000 Modelling Si-N-limited growth of diatoms; J. Plankton Res. 22(3) 447-472.

Franks P J S 1992 Phytoplankton blooms at fronts: Patterns, scales and physical forcing mechanisms; Rev. Aquat. Sci. 6(2) $121-137$.

Gadgil S 2003 The Indian monsoon and its variability; Ann. Rev. Earth Planet. Sci. 31 429-467, doi: 10.1146/annurev. earth.31.100901.141251.

Hegde S, Anil A C, Patil J S, Mitbavkar S, Venkat K and Gopalakrishna V V 2008 Influence of environmental 
settings on the prevalence of Trichodesmium spp. in the Bay of Bengal; Mar. Ecol. Prog. Ser. 356 93-101, doi: 10. 3354/meps07259.

Hillebrand H, Dürselen C D, Kirschtel D, Pollingher U and Zohary T 1999 Biovolume calculation for pelagic and benthic microalgae; J. Phycol. 35 403-424.

Hitchcock G L 1980 Diel variation in chlorophyll $a$, carbohydrate and protein content of the marine diatom Skeletonema costatum; Mar. Biol. 57 271-278.

Horstmann U 1980 Observations on the peculiar diurnal migration of a red tide Dinophyceae in tropical shallow waters; J. Phycol. 16 481-485.

Houliez E, Lizon F, Lefebvre S, Artigas L F and Schmitt F G 2013 Short-term variability and control of phytoplankton photosynthetic activity in a macrotidal ecosystem (the Strait of Dover, eastern English Channel); Mar. Biol. 160 1661-1679, doi: 10.1007/s00227-013-2218-4.

Howard A G, Comber S D W, Kifle D, Antai E E and Purdie D A 1995 Arsenic speciation and seasonal changes in nutrient availability and micro-plankton abundance in Southampton Water, U.K.; Estuar. Coast. Shelf Sci. 40(4) 435-450.

Jyothibabu R, Madhu N V, Murukesh N, Haridas P C, Nair K K C and Venugopal P 2003 Intense blooms of Trichodesmium erythraeum in the open water along east coast of India; Indian J. Geo-Mar. Sci. 32(2) 165-167.

Latha $\mathrm{T}$ P, Rao $\mathrm{K} \mathrm{H}$, Amminedu A, Nagamani $\mathrm{P}$ V, Choudhury S B, Lakshmi E, Sridhar P N, Dutt C B S and Dhadwal V K 2014 Seasonal variability of phytoplankton blooms in the coastal waters along the east coast of India; The International Archives of the Photogrammetry, Remote Sensing and Spatial Information Sciences, Volume XL-8, 1065-1071, doi: 10.5194/ isprsarchives-XL-8-1065-2014.

Laurenceau-Cornec E C, Trull T W, Davies D M, Bray S G, Doran J, Planchon F, Carlotti F, Jouandet M P, Cavagna A J, Waite A M and Blain S 2015 The relative importance of phytoplankton aggregates and zooplankton fecal pellets to carbon export: Insights from free-drifting sediment trap deployments in naturally iron-fertilised waters near the Kerguelen Plateau; Biogeosci. 12 1007-1027.

Legendre L, Demers S and Lefaivre D 1986 Biological Production at Marine Ergoclines; In: Marine Interfaces Ecohydrodynamics (Elsevier Oceanography Series) 42 129.

Lorrain A, Paulet Y M, Chauvaud L, Savoye N, Nezan E and Guerin L 2000 Growth anomalies in Pecten maximus from coastal waters (Bay of Brest, France): relationship with diatom blooms; J. Mar. Biol. Assoc. UK $\mathbf{8 0 ( 4 )}$ 667-673.

Lucas A J, Pitcher G C, Probyn T A and Kudela R M 2013 The influence of diurnal winds on phytoplankton dynamics in a coastal upwelling system off southwestern Africa; Deep Sea Res. II: Top. Stud. Oceanogr., doi: 10.1016/j. dsr2.2013.01.016.

Lucas L V, Koseff J R, Monismith S G, Cloern J E and Thompson J K 1999 Processes governing phytoplankton blooms in estuaries. II: The role of horizontal transport; Mar. Ecol. Progr. Ser. 187 17-30.

Madhu N V, Jyothibabu R, Maheswaran P A, Gerson V J, Gopalakrishnan T C and Nair K K C 2006 Lack of seasonality in phytoplankton standing stock (chlorophyll $a$ ) and production in the western Bay of Bengal; Cont. Shelf Res. 26 1868-1883.

Mari X and Kiorboe T 1996 Abundance, size distribution and bacterial colonization of transparent exopolymeric particles (TEP) during spring in the Kattegat; J. Plankton Res. 18 969-986.

McCreary J P, Murtugudde R, Vialard J, Vinayachandran P N, Wiggert J D, Hood R R, Shankar D and Shetye S 2009 Biophysical processes in the Indian Ocean. In: Indian Ocean Biogeochemical Processes and Ecological Variability, (eds) Wiggert J D, Hood R R, Naqvi S W A, Brink K H and Smith S L, doi: 10.1029/2008GM000768.

Mohanty A K, Satpathy K K, Sahu G, Hussain K J, Prasad M V R and Sarkar S K 2010 Bloom of Trichodesmium eryhraeum (Ehr.) and its impact on water quality and plankton community structure in the coastal waters of southeast coast of India; Indian J. Mar. Sci. 39(3) 323-333.

Naik R K, Hegde S and Anil A C 2011 Dinoflagellate community structure from the stratified environment of the Bay of Bengal, with special emphasis on Harmful Algal Bloom species; Environ. Monit. Assess. 182 15-30.

Nascimento F J A, Karlson A M L and Elmgren R 2008 Settling blooms of filamentous cyanobacteria as food for meiofauna assemblages; Limnol. Oceanogr. 53(6) 26362643.

Naz T, Burhan Z, Munir S and Siddiqui P J A 2013 Biovolume and biomass of common diatom species from the coastal waters of Karachi, Pakistan; Pakistan J. Bot. 45(1) 325-328.

NOAA (National Oceanic and Atmospheric Administration) 2014. http://oceanservice.noaa.gov/facts/habharm.html. Revised January 23, 2014.

Olenina I, Hajdu S, Edler L, Andersson A, Wasmund N, Busch S, Göbel J, Gromisz S, Huseby S, Huttunen M, Jaanus A, Kokkonen P, Ledaine I and Niemkiewicz E 2006 Biovolumes and size-classes of phytoplankton in the Baltic Sea HELCOM Balt; Sea Environ. Proc. 106 $144 \mathrm{p}$.

Pandi S R, Kiran R, Sarma N S, Srikanth S, Sarma V V S S, Krishna M S, Bandyopadhyay D, Prasad V R, Acharyya T and Reddy K G 2014 Contrasting phytoplankton community structure and associated light absorption characteristics of the western Bay of Bengal; Ocean Dyn. 64(1) 89-101, doi: 10.1007/s10236-013-0678-1.

Prairie J C, Sutherland K R, Nickols K J and Kaltenberg A M 2012 Biophysical interactions in the plankton: A crossscale review; Limnol. Oceanogr.: Fluids Environ 2(1) 121-145, doi: 10.1215/21573689-1964713.

Prasanna Kumar S, Muraleedharan P M, Prasad T G, Gauns M, Ramaiah N, de Souza S N, Sardesai S and Madhupratap M 2002 Why is the Bay of Bengal less productive during summer monsoon compared to the Arabian Sea? Geophys. Res. Lett. 29(24) 2235, doi: 10.1029/ 2002GL016013.

Prasanna Kumar S, Sardessai S, Ramaiah N, Bhosle N B, Ramaswamy V, Ramesh R, Sharada M K, Sarin M M, Sarupria J S and Muraleedharan U 2006. http:// drs.nio.org/drs/bitstream/2264/535/3/Report_BOBPS_ July2006.p.pdf.

Prezelin B B, Bidigare R R, Matlick H A, Putt M and Ver Hoven B 1987 Diurnal patterns of size-fractioned 
primary productivity across a coastal front; Mar. Biol. 96(4) 563-574.

Ragueneau O, Queguiner B and Treguer P 1996 Contrast in biological responses to tidally induced vertical mixing for two macrotidal ecosystems of the western Europe; Estuar. Coastal Shelf Sci. 42 645-665.

Ramamurthy V D R, Selva Kumar A and Bhargava R M S 1972 Studies on the blooms of Trichodesmium erythraeum (EHR) in the waters of the central west coast of India; Curr. Sci. 41 803-805.

Reynolds C S 2006 The ecology of phytoplankton; Cambridge University Press, 535p.

Sahu G, Satpathy K K, Mohanty A K Sankar S K 2012 Variations in community structure of phytoplankton in relation to physicochemical properties of coastal waters, southeast coast of India; Indian J. Geo-Mar. Sci. 41(3) $223-241$

Santhanam R, Srinivasan A, Ramadhas V and Devaraj M 1994 Impact of Trichodesmium bloom on the plankton and productivity in the Tuticorin Bay, Southeast coast of India; Indian J. Mar. Sci 23 27-30.

Sathyendranath S, Stuart V, Nair A, Oka K Nakane T, Bouman H, Forget M H, Maass H and Platt T 2009 Carbon-to-chlorophyll ratio and growth rate of phytoplankton in the sea; Mar. Ecol. Progr. Ser. 383 73-84, doi: 10.3354/meps07998.

Satpathy K K, Mohanty A K, Sahu G, Prasad M V R, Venkatesan R, Natesan U and Rajan M 2007 On the occurrence of Trichodesmium erythraeum (Ehr.) bloom in the coastal waters of Kalpakkam, east coast of India; Indian J. Sci. Technol. 1(2), doi: 10.17485/ijst/2007/ v1i2/29204.

Corresponding editor: D SHANKAR
Shankar D, Vinayachandran P N and Unnikrishnan A S 2002 The monsoon currents in the north Indian Ocean; Progr. Oceanogr. 52 63-120.

Shetye S, Sudhakar M, Jena B and Mohan R 2013 Occurrence of nitrogen fixing cyanobacterium Trichodesmium under elevated pCO2 conditions in the western Bay of Bengal; Int. J. Oceanogr. 350465, doi: 10.1155/2013/ 350465

Siegel D A, Behrenfeld M J, Maritorena S and McClain et al. 2013 Regional to global assessments of phytoplankton dynamics from the SeaWiFS mission; Rem. Sens. Environ. $13577-91$.

Smayda T J 1997 What is a bloom? A commentary; Limnol. Oceanogr. 42(5) 1132-1136.

Sun J and Liu D 2003 Geometric models for calculating cell biovolume and surface area for phytoplankton; J. Plankton Res. 25 1331-1346.

Tilstone G H, Angel-Benavides I M, Pradhan Y, Shutler J D, Groom S and Sathyendranath S 2011 An assessment of chlorophyll- $a$ algorithms available for SeaWiFS in coastal and open areas of the Bay of Bengal and Arabian Sea; Rem. Sens. Environ. 115 2277-2291.

Trigueros J M and Orive E 2000 Tidally driven distribution of phytoplankton blooms in a shallow, macrotidal estuary; J. Plankton Res. 22(5) 969-986.

UNESCO 1978 Phytoplankton manual. Monographs on oceanographic methodology; (ed.) Sournia A. UNESCO technical paper 28 337p.

Vinayachandran P N and Mathew S 2003 Phytoplankton bloom in the Bay of Bengal during the northeast monsoon and its intensification by cyclones; Geophys. Res. Lett. 30, doi: 10.1029/2002GL016717. 